\title{
Pemeriksaan Jumlah Kapang Sebagai Indikator Kualitas Terasi Di Pasar Tambaksari Surabaya
}

\author{
Dita Artanti ${ }^{1}$, Fajrul Udkhiyah Adilah ${ }^{2}$, dan Fitrotin Azizah ${ }^{3}$ \\ ${ }^{122) 3)}$ Prodi DIII Analis Kesehatan Universitas Muhammadiyah Surabaya \\ dita.artanti3009@yahoo.com
}

\begin{abstract}
Tanggal

Submit:

18 Juni 2019

Tanggal

Review:

24 Juni 2019

Tanggal

Publish Online:

2 Oktober 2019

The main problem that occurs in the community is the lack of awareness of the importance of hygiene during the manufacture and storage of shrimp paste. This can trigger one of the contaminations originating from microorganisms including mold. The aimed of this study was to determine the number of molds as an indicator of shrimp paste quality in the Tambaksari market in Surabaya. This research is descriptive. The population of this research is shrimp paste traders in Tambaksari market in Surabaya. The research variable is the number of molds in the shrimp paste in the packaging without a brand in the Tambaksari market in Surabaya. Data on the number of molds was tabulated and analyzed descriptively by calculating the percentage of samples that were of good quality and not good. The results of the research on the number of mold colonies on shrimp paste sold in the Tambaksari market in Surabaya showed that the number of mold colonies in shrimp paste samples was safe to consumed because the amount was $<2 \times 10^{2}$ colonies / gr, the average percentage of all shrimp paste samples was $100 \%$ good quality. The highest growth rate of mold colonies was $19 \times 10^{1}$ colonies / gr and the lowest growth rate of mold colonies was $0 \times 10^{1}$ colony / gr.
\end{abstract}

Keywords : The Number of Mold, Shrimp paste

\section{PENDAHULUAN}

Terasi adalah suatu jenis penyedap makanan berbentuk pasta, berbau khas hasil fermentasi udang, ikan, atau campuran keduanya dengan garam atau bahan tambahan lain. Pasta ikan atau udang biasanya terbuat dari berbagai jenis ikan air tawar dan laut serta udang (Anggo dkk., 2014).

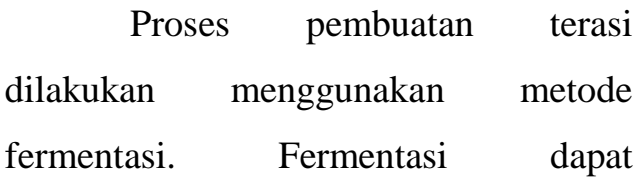

menghasilkan amonia yang menimbulkan terasi berbau menyengat. Di dalam masakan, terasi digunakan sebagai penyedap dan menimbulkan cita rasa (flavouring agent) (Kemenristek, 2015).

Selama proses penyimpanan dan fermentasi banyak mikroorganisme yang ikut berkembang, diperkirakan jenisjenis bakteri asam laktat seperti Leuconostoc mesenteroids, Pediococcus cerevisiae dan Lactobacillus plantarum 
berkembang. Beberapa jenis khamir juga

diperkirakan ikut berkembang dalam

fermentasi (Buckle dkk., 2009).

Pada umumnya sangat jarang dijumpai adanya terasi yang rusak atau busuk. Hal ini merupakan salah satu keunggulan dari produk terasi yang jarang dijumpai pada produk olahan / awetan lain. Menurut Sukesi (2013) daya tahan terasi rebon memiliki daya tahan yang lebih lama, meskipun terasi rebon tersebut tanpa bahan pengawet kecuali dengan campuran garam sebagai pengawetnya.

Produk-produk pangan yang disimpan terlalu lama akan mengalami penurunan kualitas sehingga akan menjadi rusak sama sekali meskipun sebelumnya sudah diawetkan. Namun tidak demikian halnya dengan terasi. Produk terasi justru sebaliknya, makin lama disimpan, aroma dan cita rasanya semakin meningkat (Sukesi, 2013).

Penyebab yang sering ditemukan di lapangan ataupun secara klinis adalah kontaminasi terasi oleh kapang. Infeksi yang umum terjadi yaitu adanya alergi, gangguan kehamilan dan juga keracunan. Infeksi fungi ini bisa menyebabkan bahaya yang tidak terduga. Pada dasarnya semua resiko yang lebih buruk bisa terjadi jika infeksi fungi tidak mendapatkan perawatan yang tepat. Memelihara lingkungan agar tetap bersih menjadi salah satu cara pencegahan bahaya fungi (Vivianti, 2015).

Kapang dan khamir merupakan kelompok mikroorganisme yang termasuk filum Fungi. Beberapa contoh kapang dan khamir penyebab penyakit yang dapat ditemukan di perairan, baik pada kolam, sungai, danau maupun laut adalah; Aspergillus spp, Penicillium spp., Pythiopsis, Saprolegnia parasitica, Isoachlya, Leptolegnia, Candida spp, dan Rhodotorulla spp. (Suryawirya, (1993)dalam Noverita(2009)).

Menurut Ganjar (2006) dalam Sanjaya (2011) Pada umumnya pertumbuhan kapang dipengaruhi oleh faktor substrat, kelembapan, suhu, derajat keasaman substrat $(\mathrm{pH})$. terasi sering terkontaminasi kapang dalam kelompok mesofil karena terasi disimpan dalam suhu $25^{\circ} \mathrm{C}-30^{\circ} \mathrm{C}$. beberapa jenis khamir tertentu bahkan dapat tumbuh pada $\mathrm{pH}$ yang cukup rendah, yaitu $\mathrm{pH}$ 4,5 - 5,5. Makanan yang difermentasi khususnya terasi memiliki $\mathrm{pH}$ di bawah 7,0 sehingga kapang dapat mengkontaminasi terasi.

Masyarakat Tambaksari Surabaya sangat menyukai masakan yang berbahan terasi, Hal ini dapat dilihat dari banyaknya penjaja makanan yang menggunakan terasi sebagai bumbu pendamping. Berdasarkan latar belakang di atas, maka peneliti ingin mengetahui Jumlah kapang sebagai indikator 
The Joumal Of Muhammadiyah Medical Laboratiory

Vol.2 No.2 Mei2019

p-ISSN: 2597-3681 e-ISSN:26142805

kualitas terasi di pasar Tambaksari Surabaya.

\section{METODE PENELITIAN}

Jenis penelitian ini adalah penelitian deskriptif. Populasi dan sampel penelitian ini adalah pedagang terasi di Pasar Tambaksari Surabaya.

Penelitian dilakukan di Laboratorium Mikrobiologi Prodi D3 Analis Kesehatan Fakultas Ilmu Kesehatan Universitas Muhammadiyah Surabaya. Penelitian dilaksanakan pada bulan Desember 2017 dan berakhir pada bulan Juli 2018. Terasi pada penelitian ini dikategorikan:

1. Baik: apabila ditemukan jumlah kapang $\leq 2 \times 10^{2}$ koloni / gr (Memenuhi syarat SNI NO 7388:2009).

2. Tidak baik: apabila ditemukan jumlah kapang $\geq 2 \times 10^{2}$ koloni / gr (Tidak memenuhi syarat SNI NO 7388:2009).

Menurut Badan Standarisasi Nasional tahun 2009. Makanan yang merupakan kondimen atau bumbu dalam jenis cemaran mikroba atau kapang jumlah batas maksimumnya $2 \times 10^{2}$ koloni / gr (SNI NO 7388:2009).

Alat yang digunakan dalam penelitian ini adalah Autoclave, cawan Petri, Api bunsen, Erlemeyer, Pipet ukur, Pipet volume,Incubator,
Pengaduk, Ose bulat, Plate, Kantong plastik (untuk pengambilan sampel ).

Bahan yang digunakan dalam penelitian ini adalah Terasi (sampel pemeriksaan), SDA (Sabouraud Dextrose Agar), Aquadest, dan antibiotik Chloramphenicol.

Pengambilan sampel dalam keadaan bersih dan steril, sampel terasi diperoleh dari penjual yang telah ditentukan sebelumnya, sampel diambil secukupnya lalu dimasukkan ke wadah yang steril yang sudah diberi label dengan kode nomor.

Pemeriksaan jumlah kapang dengan cara sampel ditimbang sebanyak $1 \mathrm{gr}$, lalu dimasukkan ke dalam mortar yang telah steril, kemudian ditumbuk sampai halus, sampel dimasukkan ke dalam Erlenmeyer yang berisi aquadest sebanyak $9 \mathrm{ml}$ dan dihomogenkan dianggap sebagai pengenceran $10^{-1}$. Lalu terasi ditunggu mengendap dan diambil air nya sebanyak $1 \mathrm{ml}$ dan dimasukkan ke dalam cawan Petri yang telah disteril. Kemudian ditambahkan media SDA (yang telah dicampur chloramphenicol) steril sebanyak 15-20 ml ke dalam cawan Petri. Kemudian cawan Petri dibalik setelah SDA membeku dan diinginkubasi selama 4 hari pada suhu $25^{\circ} \mathrm{C}$ atau suhu kamar. Dihitung koloni kapang setelah 4 hari. Dilaporkan dan Dicatat hasil sebagai jumlah kapang koloni/gr. 


\section{Hasil Penelitian}

Hasil penelitian pemeriksaan jumlah kapang sebagai indikator kualitas terasi di pasar Tambaksari Surabaya dapat dilihat pada Tabel 1.

Tabel 1. Jumlah Kapang Sebagai Indikator Kualitas Terasi di Kecamatan Tambaksari Surabaya

\begin{tabular}{|c|c|c|c|}
\hline No & Kode Sampel & Hasil Jumlah Kapang (Koloni/gr) & Kualitas \\
\hline 1 & $\mathrm{~K} 1$ & $8 \times 10^{1}$ & Baik \\
\hline 2 & $\mathrm{~K} 2$ & $12 \times 10^{1}$ & Baik \\
\hline 3 & K3 & $9 \times 10^{1}$ & Baik \\
\hline 4 & K4 & $12 \times 10^{1}$ & Baik \\
\hline 5 & K5 & $3 \times 10^{1}$ & Baik \\
\hline 6 & K6 & $3 \times 10^{1}$ & Baik \\
\hline 7 & K7 & $2 \times 10^{1}$ & Baik \\
\hline 8 & K8 & $6 \times 10^{1}$ & Baik \\
\hline 9 & K9 & $19 \times 10^{1}$ & Baik \\
\hline 10 & K10 & $15 \times 10^{1}$ & Baik \\
\hline 11 & K11 & $3 \times 10^{1}$ & Baik \\
\hline 12 & K12 & $2 \times 10^{1}$ & Baik \\
\hline 13 & K13 & $1 \times 10^{1}$ & Baik \\
\hline 14 & K14 & $2 \times 10^{1}$ & Baik \\
\hline 15 & K15 & $1 \times 10^{1}$ & Baik \\
\hline 16 & K16 & 0 & Baik \\
\hline 17 & K17 & $6 \times 10^{1}$ & Baik \\
\hline 18 & K18 & $4 \times 10^{1}$ & Baik \\
\hline 19 & K19 & $5 \times 10^{1}$ & Baik \\
\hline 20 & K20 & $1 \times 10^{1}$ & Baik \\
\hline 21 & K21 & $1 \times 10^{1}$ & Baik \\
\hline 22 & K22 & $1 \times 10^{1}$ & Baik \\
\hline 23 & K23 & $3 \times 10^{1}$ & Baik \\
\hline 24 & K24 & $2 \times 10^{1}$ & Baik \\
\hline 25 & K25 & $4 \times 10^{1}$ & Baik \\
\hline 26 & K26 & $8 \times 10^{1}$ & Baik \\
\hline 27 & K27 & $11 \times 10^{1}$ & Baik \\
\hline 28 & K28 & $7 \times 10^{1}$ & Baik \\
\hline 29 & K29 & 0 & Baik \\
\hline 30 & K30 & 0 & Baik \\
\hline \multicolumn{2}{|c|}{ Jumlah } & 151 & \\
\hline \multicolumn{2}{|c|}{ Rata-rata } & 5,033 & \\
\hline
\end{tabular}

Keterangan :

K1 s/d K30 : Sampel Kapang Kode 1 sampai dengan 30 
Berdasarkan Tabel 1 di atas menunjukkan bahwa seluruh sampel terasi berkualitas baik dengan nilai ratarata pertumbuhan koloni paling tinggi pada kode sampel K9 yaitu sebesar $19 \mathrm{x}$ $10^{1}$ koloni/gr. Kemudian pertumbuhan koloni kapang terendah pada kode sampel K16, K29, dan K30 yaitu sebesar $0 \times 10^{1}$ koloni/gr.

Hasil tersebut di atas sesuai dengan peraturan dari Badan Standarisasi Nasional tahun 2009. Makanan yang merupakan kondimen atau bumbu dalam jenis cemaran mikroba atau kapang jumlah batas maksimumnya $2 \times 10^{2}$ koloni / gr (SNI NO 7388:2009).

Hasil penelitian ini menunjukkan bahwa terasi yang dijual di pasar kecamatan Tambaksari Surabaya tidak berpotensi menyebabkan terjadinya resiko gangguan kesehatan yang diakibatkan oleh kapang. Hal ini dibuktikan dengan jumlah sampel terasi yang memiliki koloni kapang lebih rendah dan memenuhi syarat SNI NO 7388:2009. Meskipun dalam terasi terdapat koloni kapang, tetapi jumlah koloni kapang masih di angka standart sehingga terasi yang mengandung kapang yang dijual di pasar Kecamatan Tambaksari Surabaya masih bisa dikonsumsi.

\section{PEMBAHASAN}

Kapang adalah fungi multiseluler yang mempunyai filamen dan pertumbuhannya pada makanan mudah dilihat karena penampakannya yang berserabut seperti kapas. Pertumbuhannya mula-mula akan berwarna putih, tetapi jika spora telah timbul akan terbentuk berbagai warna tergantung dari jenis kapang (Vivianti, 2015).

Terasi dapat terkontaminasi dengan kapang, hal itu dapat disebabkan oleh berbagai macam faktor yang ada disekitar terasi tersebut. Diantaranya adalah tempat penyimpanan bahan baku terasi yang tidak sesuai, tidak semua penjual menggunakan bahan baku terasi yang baik sehingga mempengaruhi kualitas terasi yang dihasilkan, tempat berjualan terasi yang dekat dengan sumber cemaran, dan yang paling penting adalah proses pengolahan terasi. Pada proses pengolahan terasi ada kemungkinan terjadinya kontaminasi oleh kapang yang dapat menghasilkan racun. Racun yang dikeluarkan oleh Aspergillus adalah senyawa Alfatoksin yang berbahaya bagi kesehatan, pada proses pengolahan makanan seperti penyangraian dan penggorengan hanya dapat mengurangi kandungan Alfatoksin sebanyak $73-87 \%$, dengan demikian kapang masih dapat tumbuh dan 
The Joumal Of Muhammadiyah Medical Laboratiory

Vol.2 No.2 Mei2019

p-ISSN: 2597-3681 e-ISSN:26142805

berkembang biak dengan baik( Safika, 2008).

Meskipun jumlah kapang pada terasi masih dalam angka standart, ada beberapa hal yang mengakibatkan masyarakat lebih beresiko terkena penyakit yang disebabkan oleh kapang diantaranya usia, penderita HIV/AIDS, wanita hamil, sistem imunitas yang kurang baik dapat mengakibatkan terkontaminasi penyakit yang disebabkan oleh kapang sehingga untuk mecegah terjadinya kontaminasi akibat kapang terasi sebaiknya membatasi dalam mengkonsumsi terasi (Dewanto, 2012).

Pada umumnya pertumbuhan kapang dipengaruhi oleh faktor substrat, kelembapan, suhu, derajat keasaman substrat $(\mathrm{pH})$

Substrat adalah sumber nutrien utama bagi kapang. Nutrien-nutrien baru dapat dimanfaatkan sesudah kapang mengekskresi enzim-enzim ekstraseluler yang dapat mengurai senyawa-senyawa kompleks dari substrat tersebut menjadi senyawa-senyawa yang lebih sederhana. Kapang yang tidak dapat menghasilkan enzim sesuai komposisi subtrat dengan sendirinya tidak dapat memanfaatkan nutrien-nutrien dalam substrat tersebut, Sehingga Terasi dapat dijadikan substrat sebagai tempat berkembangbiaknya kapang (wijesuriya dkk., 2015).
Kelembapan faktor ini sangat penting untuk pertumbuhan kapang. Pada umumnya kapang tingkat rendah sepertiRhizopus atau Mucor memerlukan lingkungan dengan kelembapan nisbi 90\%, sedangkan kapang Aspergillus, Penicillium, Fusarium, banyak Hyphomycetes lainnya dapat hidup pada kelembapan yang lebih rendah, yaitu $80 \%$. Dengan mengetahui sifat-sifat fungi ini penyimpanan bahan pangan dan materi lainnya dapat di cegah dari kerusakan. Cara penyimpanan terasi yang sebagian besar disimpan di wadah dengan kelembapan yang tinggi mengakibatkan terasi mudah terkontaminasi kapang.

Berdasarkan kisaran suhu lingkungan yang baik untuk pertumbuhan, kapang dapat dikelompokkan sebagai kapang psikrofil, mesofil, dan termofil. Secara umum pertumbuhan untuk kebanyakan kapang adalah sekitar 25 $30{ }^{\circ} \mathrm{C}$. Beberapa jenis kapang bersifat psikrotrofik yakni dapat tumbuh baik pada suhu lemari es dan ada kapang yang masih bisa tumbuh secara lambat pada suhu dibawah suhu pembekuan, misalnya $-5{ }^{\circ} \mathrm{C}$ sampai $-10{ }^{\circ} \mathrm{C}$. Selain itu, ada jamur yang bersifat termofilik yakni mampu tumbuh pada suhu tinggi. Mengetahui kisaran suhu pertumbuhan suatu fungi adalah sangat penting, terutama bila isolat-isolat 
tertentu atau termotoleran dapat memberikan produk yang optimal meskipun terjadi peningkatan suhu, karena metabolisme funginya. Oleh sebab itu terasi sering terkontaminasi kapang dalam kelompok mesofil karena terasi disimpan dalam suhu $25^{\circ} \mathrm{C}-30{ }^{0} \mathrm{C}$ (wijesuriya dkk., 2015).

$\mathrm{pH}$ substrat sangat penting untuk pertumbuhan Kapang , karena enzim-enzim tertentu hanya akan mengurai suatu substrat sesuai dengan aktivitasnya pada $\mathrm{pH}$ tertentu. Umumnya Kapang menyenangi $\mathrm{pH}$ dibawah 7,0. Namun beberapa jenis khamir tertentu bahkan dapat tumbuh pada $\mathrm{pH}$ yang cukup rendah, yaitu $\mathrm{pH}$ 4,5 - 5,5. Makanan yang difermentasi khususnya terasi memiliki $\mathrm{pH}$ di bawah 7,0 sehingga kapang dapat mengkontaminasi terasi (wijesuriya dkk., 2015).

\section{SIMPULAN DAN SARAN}

Berdasarkan hasil penelitian yang telah dilakukan dapat disimpulkan bahwa persentase seluruh sampel terasi adalah $100 \%$ berkualitas baik. Sehingga terasi-terasi ini tergolong aman dikonsumsi.

Beberapa saran dalam penelitian ini adalah masyarakat harus lebih menjaga kebersihan sedangkan bagi peneliti selanjutnya yaitu perlu penelitian lebih lanjut untuk mengetahui cemaran logam berat, cemaran mikrorganisme lain seperti Coliform, Angka Lempeng Total, serta kriteria uji lain sehingga kelayakan terasi yang akan dikonsumsi masyarakat lebih terjamin keamanannya.

\section{DAFTAR PUSTAKA}

Afrianto E. dan E. Liviawaty, 2005. "Pengawetan dan Pengolahan Ikan”. Kanisius, Yogyakarta.

Anggo, A. D., F. Swastawati., W. F. Ma'ruf dan L. Rianingsih. 2014. "Mutu organoleptik dan kimiawi terasi udang rebon dengan kadar garam berbeda dan lama fermentasi”. Diakses melalui http://undip.ac.id pada tanggal 18 Desember 2018 jam 18.00.

Antara, N.S., 2009. "Potensi Pangan Hasil Laut Terfermentasi". Diakses melalui http://staff.unud.ac.id pada tanggal 25 Maret 2018.

Buckle, K.A., R.A. Edwards, G.H. Fleet, dan M. Wooton, 2009. "Ilmu Pangan”. Penerjemah: Hari Purnomo dan Adiona. UI-Press, Jakarta.

Cherlin. 2016. "Peningkatan Mutu Terasi Kaya Antioksidan dan Protein Berbahan Kedelai, Jagung, dan Ikan Sarden (Sardinella Lemuru) Terfermentasi “ Fakultas Pertanian Universitas Sumatra Utara.

Depkes RI. 2009. "Undang-Undang Republik Indonesia Nomor 36 Tahun 2009 tentang Kesehatan”. Jakarta. 
Dewanto,A.G.,2012.“Aspergillus Niger “. Diakses melalui http://teknoganik.blogspot.com/20 12/04aspergillus-niger.html. Pada tanggal 18 April 2018 jam 15.00.

Kemenristek, 2015. "Terasi dan Petis". Diakses melalui padhttp://warintek.ristek.go.id pada tanggal 9 Maret 2018 jam 10.30 .

Khadijah, S. 2016. "Uji Komposisi Bahan Baku Terasi Pada Alat Penumbuk Mekanis". Fakultas Pertanian Universitas Sumatra Utara.

Maryam, R. 2002. "Mewaspadai Bahaya Kontaminasi Mikotoksin Pada Makanan". Diakses melaui http://tumoutou.net/702_04212/ro msyah_m.htm. pada tanggal 20 April 2018.

Noverita. 2009. "Identifikasi Kapang dan Khamir Penyebab Penyakit Manusi Pada Sumber Air Minum Penduduk Pada Sungai Ciliwung Dan Sumber Air Sekitarnya" Volume 2. Nomer 2.

Pratiwi, S.T. 2008. "Mikrobiologi Farmasi”. Jakarta: Erlangga. Hal. 38-45.

Rahmayati, R. Riyadi, P.H., \& Rianingsih, L. 2014 "Perbedaan Konsentrasi Garam Terhadap Pembentukan Warna Terasi Udang Rebon (Acetes sp.) Basah". Volume 3. Nomer 1.

Ramadhanny, C.N., 2017. "Terasi". Diakses melalui http://www.kerjanya. net/faq/18074-terasi.html pada tanggal 30 januari 2018 jam 15.45 .
Riadi, L., 2008. "Teknologi Fermentasi”. Yogyakarta: Graha Ilmu.

Safika, 2008. “ Korelasi Aspergillus Flavus Dengan Konsentrasi Alfatoksin B1 PadaIkanKayu". Diakses melalui http:/lp.ezdownloadpro.info/eb3/? $\mathrm{q}=$ KORELASI+Aspergillus+flavu s+DENGAN+KONSENTRASI+ ALFATOKSIN+B1+PADA+IKA $\mathrm{N}+\mathrm{KAYU}+$ pdf.Pada tangal18 April 2018 jam 17.45.

Sari, N. I., Edison dan Mus, S. 2009. "Kajian Tingkat Penerimaan Konsumen terhadap Produk Terasi Ikan dengan Penambahan Ekstrak Rosela". Berkala Perikanan Terubuk. 37 (2) : 91103. ISSN 0126-6265.

Sizah. 2005. "Analisa MPN Coliform Pada Terasi yang Di jual Di pasar Tamberu Kecamatan Sokobanah Kabupaten Sampang Madura” Fakultas Ilmu Kesehatan Universitas Muhammadiyah Surabaya.

Sukesi. 2014. “ Loyalitas Pelanggan Produk Terasi Rebon "Surabya : Smartekindo.

Sunnara, R. 2011. Jangan Gengsi dengan Terasi. Kenanga Pustaka Indonesia. Banten.

Susilowati. 2010. "Hubungan antara sudut interinsisal dengan derajat konveksitas profil jaringan lunak wajah pada suku bugis". Jurnal Dentika Dent. Volume 14. Nomer 2.

Suwandi. 2015. "Uji Komposisi Bahan Baku Terasi Dengan Menggunakan Alat Pencetak Terasi". Fakultas Pertanian Universitas Sumatra Utara. 
Syah, D. 2005. "Manfaat dan Bahaya Tambahan Pangan".Himpunan Alumni Fakultas Teknologi Pertanian IPB. Bandung.

Utama, H,. 2008. "Parasitologi Kedokteran" Jakarta: Penerbit buku FKUI.

Vivianti, M. 2015. “Kapang”. Diakses melalui http://mayavivianti.blogspot.co $\mathrm{m} /$ 2015/04/kapang.html pada tanggal 7 april 2018

Waluyo, L. 2007."Mikrobiologi Umum". UMM Press. Malang.

World Health Organization (WHO), 2009. "Penyakit Bawaan Makanan: Fokus Pendidikan Kesehatan". Jakarta: EGC, pp.13.

Wijesuriya, T.M., Kottahachchi, J. Gunasekara, J.T.D.C.P., 2015 "Aspergillus Species: An Emerging Pathogen In Onychomycosis Among Diabetics" Volume 19. Nomer 6. 